
This repont was prepared as an sccount of work sponsored by the United Stutes Governutiont. Neithw the Unired States not the United Stotes Atomic Ensrgy Commission. noz any of their emploves, nor any of their contractors, subeentrectots, or their employees, makes any warranty. express or implied, or assumes any lcgal liability or responsibility for the accuracy, completencss or usefulness of any intormation, apparatus. profuct or process disclosed, or represen:3 that its use would not inftinge privately owned rights.

Printed in the United Stutes of America. Available from

National Technical Intormation Service

U. S. Department of Commerce 6285 Port Aoyal Fosd

Springlield, Virginis 22151

Price: Printed Copy S4.00; Mleribltehe $\mathbf{5 0 . 9 5}$ 
L.A.5351-MS

UC.41

ISSUED: Ostober 1973

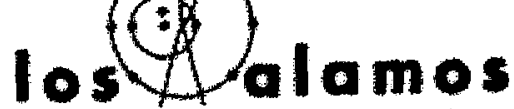
octontile labormiory

of the Universily of celifornte LOS AtAMOS. MIW MEXICO 67 SAL

1

\section{A Monitor for Radioactive Gas in the LAMPF Accelerator Beam Channel}

by

Morris J. Engalke

Harvey I. Israel

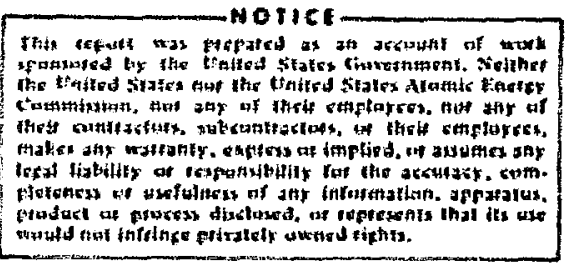


A MOYITOR POR RADTOACTIVE GAS IN FHE LAMPE ACCELERATOR DEN CHANNEL

by

Morris J. Engelke and Harvey I. Isxael

\section{ABSTRACT}

Beam loss in acenelerotor structures and target arcas gives zise to radioactive gases formed by interaction of secondary partales in air. A method of monitoring the aif in the LuPF acceleratsy bean channel using a 51.511ter ion chamber is described. A method for control of thase radionetive gases is discussed.

\section{INTroductron}

The Clinton D. Arderton Meson Physies Factility (Lhitip) is a linear proton accelerator composed of a crockcroft-Walton acceleracor injector, the beam-transport system, the eccelerator proper, the bean switchyard, and experimental areas.

Proton injection from the crockcroftWalton aecelerator is at $750 \mathrm{keV}$. The first part of the acceierator operates at $201 \mathrm{MHz}$ to ralue the proton beam to an energy of $100 \mathrm{HeV}$. The rest of the accelerator operates at $805 \mathrm{MHz}$ to bring the beam to its design energy of 800 hev.

Beam pulses can be as long as 500 usec with a peak current of $17 \mathrm{~mA}$ and a repetition rate of 120 pps. Bean loss has been cstimated to bo $100 \mathrm{nA} / \mathrm{m}$ in the $361-m-10 n g$, 201-Mllz section $\mathrm{di}^{2}$ ? $2 \mathrm{nA} / \mathrm{m}$ in th- $732 \mathrm{~m}-$ long, 605-Milz section. Experience has shown that beam loss in accelerator structures and target areas will give rise to radioactive gas formed by the interaction of secondary particles in air. The principal types of radionuclides thus generated are well known, and their potential radiation hazard has already been estimated. ${ }^{1-5}$ Radioactive gases thus formed will be predominantly ${ }^{13} \mathrm{~N}, 150,{ }^{11} \mathrm{C}$, and ${ }^{4} \mathrm{Ar}$. The half- lives of all but argon $\left(T_{L_{3}}=1.83 \mathrm{~h}\right)$ are 20 min or iess.

In the beam channel, it is sufficient to monitor the ais for gaseous radioactivity and pormfe lts release only when the detection instrunent shows essentially no more tnan two to three times normal bachground activity. The gas can be analyzed in greater Jotafl if conditions warrant. The time required for the air activity to decay to background levels will be shozt compared to decay time of tho induced activity in accelerator structures. Thus, personnel occupancy will be governed by the radiation emanating from accelerator components in the beam channel, not by radloactive air concentrations.

The beam channel will have barriers to isolate the air at the heginning of the 201Mhz section and at the end of che 805-Mkz section. These barriers will not necessarily be airtight, but thoy will minimize natural leakage and convection. portable air samplers with provisions for arawing the aff from the bean channel to the dector and returning it to the bear channei are located in the service corridor, $230 \mathrm{ft}$ abose the beam channel. This air is monitored for radioactive gases and ozone. 


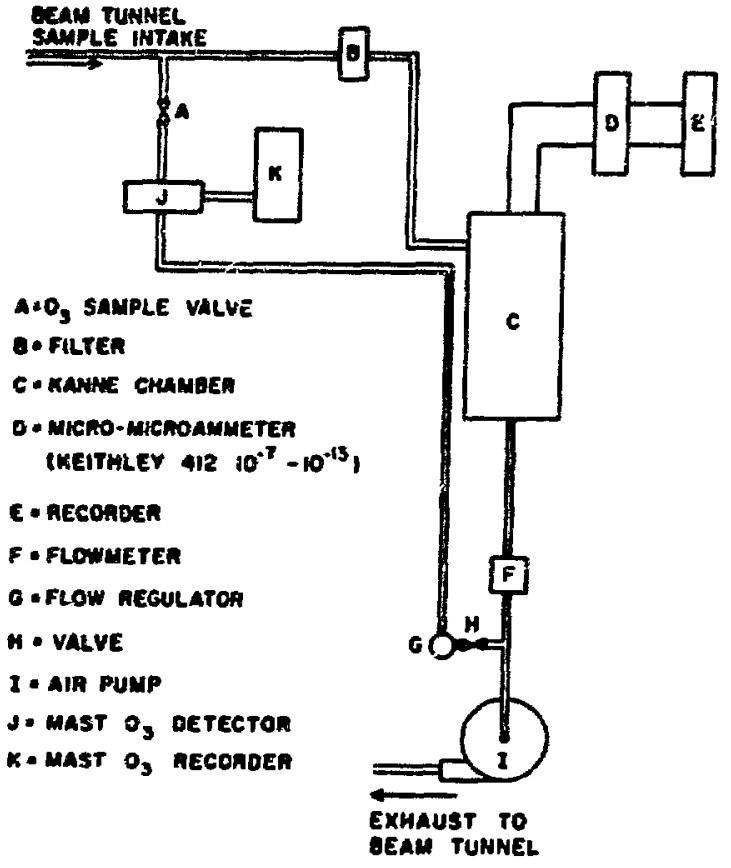

Fig. 1. The Kanne air-monitoring system.

A Kanne-type air-ionization instrument is used to monitor the beam-channel air for radioactive gases, and a Mast Development Company detector is used to measure ozone.

II. THE KANNS Chamber

Figure 1 is a block diagram of the kanne air-monitoring system. This is a mobile unit inounted on a four-wheeled, industrialtype wagon for movement to areas where air measurements are desired (Fig. 2). A filter has been placed ahead of the chamber to remove oust. The chamber is composed of concentric cylinders in which the air passes by a deionizer before entering the sensitive volume of the chamber. When the air at the rate of $0.00142 \mathrm{~m}^{3} \mathrm{sec}^{-1}$ (3 $\mathrm{ft}^{3} \mathrm{~min}^{-1}$ ) passes into the 51.5-1iter sensitive volume of the chamber, it is forced to pass first down one side and then up the other side of the chamber before aischarge. The current produced by ionization within the Iranne chamber 18 measured by a picoammeter and continuously recorded.

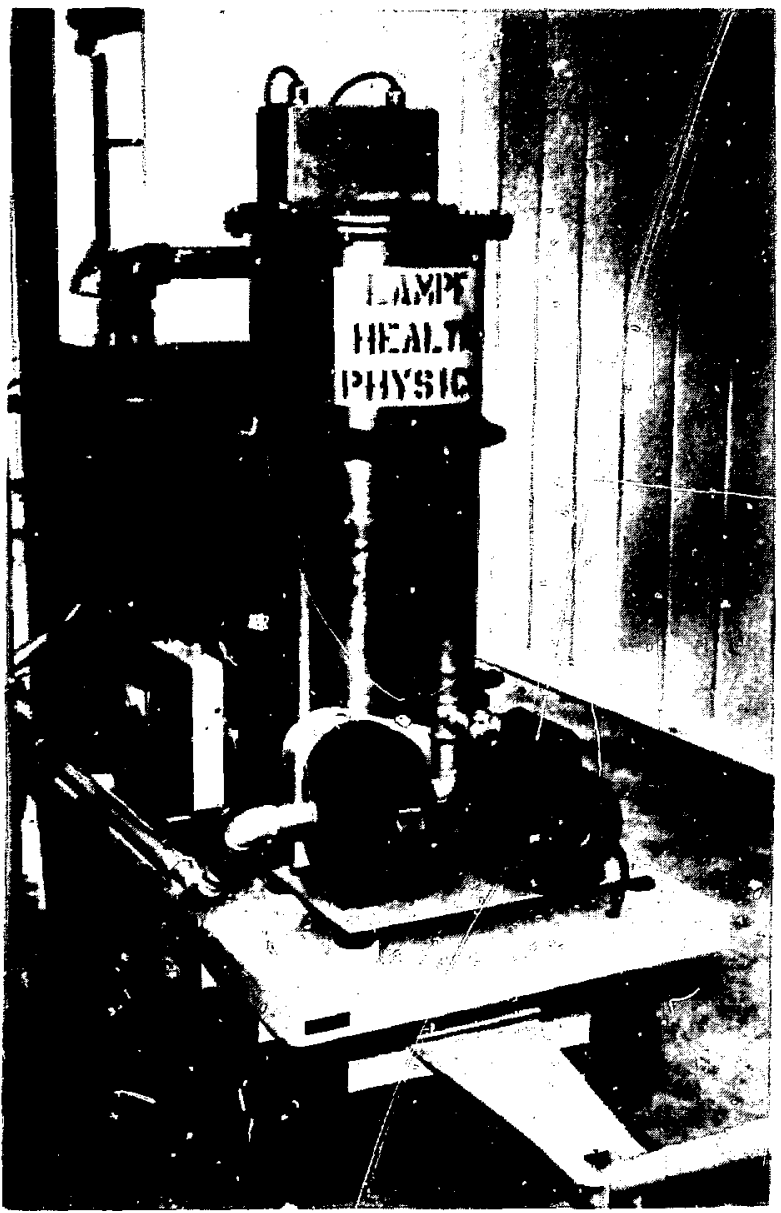

Fig. 2. The mobile Kanne chamber and Mast $\mathrm{O}_{3}$ deteczor unit.

The Kanne chamher has been extensively used to measure ${ }^{3} \mathrm{H}$ concentrations in air. 5,6 This type of instrument has been used to monitor more energetic gaseous radioisotopes successfully with reduced efficiency. If the gas is not a pure $B$ emitter, the contribution to the current from interaction of $\gamma^{\prime} s$, and eventually of conversion and auger electrons, must be taken into account. The physical dimensions of the Kanne chamber make experimental determination of the backscatter and absorption of higher energies of betas or electrons very difficult. Elsewhere, ${ }^{85} \mathrm{Kr}$ has been used to calibrate ion zation-type instruments and proportional counters. 7.8 There is an overresponse to 


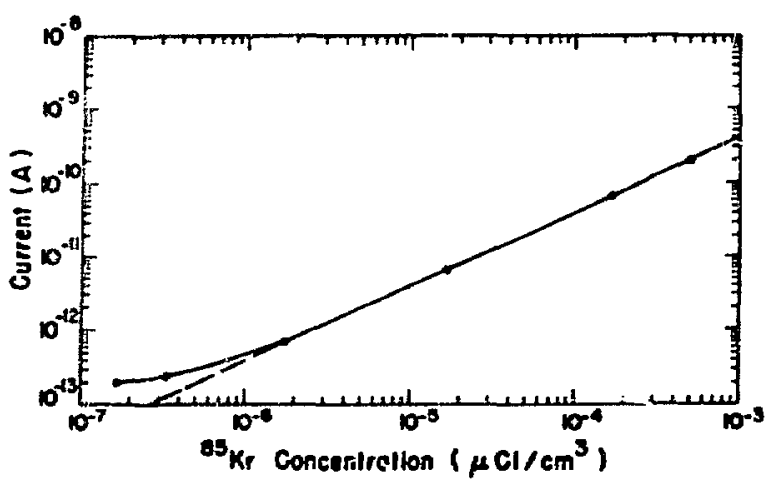

Fig. 3. Kanne-chamber calibration to $85 \mathrm{kr}$.

most radioactive gases if ${ }^{85} \mathbf{K r}$ has been used as a calibration standard. ${ }^{8}$ This is true for radioactive gases, such as $12 \mathrm{C}$, ${ }^{13} \mathrm{~N}$, and 150 , that are positron emitters. Sensitivity calculations for the Ranne-type ionization chamber show that the ${ }^{65} \mathrm{Kr}$ sensitivity is 858 that of $41 \mathrm{Ar} .6,5$

Because of high ozone concentrations at the Electron Prototype Accelerator, it was originally thought that the same conditions might be true for LAMPF ${ }^{10}$ This has not been so; ozone has not been detected in the bean channel. The ozone detector used is discussed in the appendix.

\section{CALIBRATION PROCEDURE}

A $1-C i{ }^{85} \mathrm{Kr}$ source was acquired so that the Kanne chamber might be cal.ibrated to this $B$ emitter $\left(E_{\mathrm{max}}=670 \mathrm{kev}\right)$. The source was encapsulated in a $32.5-\mathrm{Em}^{3}$ glass vial at standard temperature and pressure. This source was subseguently mixed with a nitrogen carrier to produce a $54-4 \mathrm{Ci} / \mathrm{cr}^{3}$ mixture. At the LASI Occupational Health Laboratcry, a $16-\mathrm{m}^{3}$ airtight chamber was used for calibration. Al quot parts of the ${ }^{85} \mathrm{Kr}$ concentration were introduced into this chamber, and air was drawn f gom it to the kanne instrument and returned. Figure 3 shows the result of these measurements.

\section{OPERATING INFOMMGTION}

As shown above, the kanne chamber can be used to detect radiouctive gas in air. The background of 1.5 to $2 \times 10^{-13} \mathrm{~A}$ is due

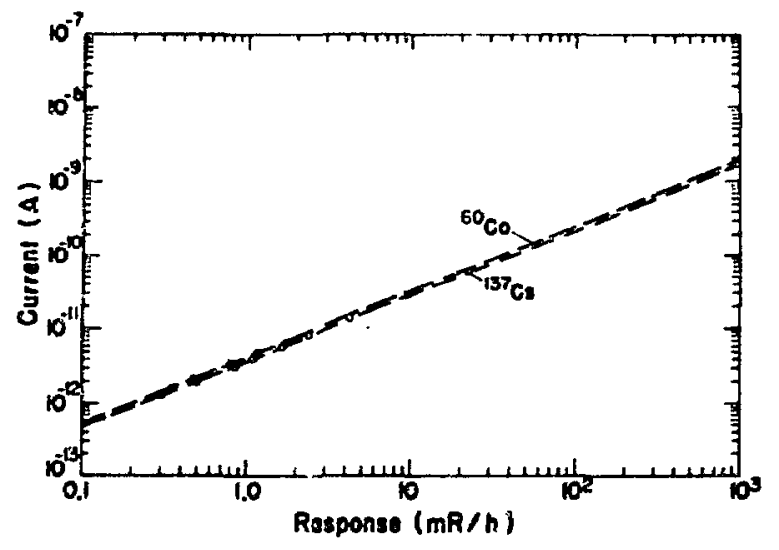

Fig. 4. Kanne-chamber tesponse to gamma radiation.

to naturally occurring radioactivity. This limits the low-level measurement to $2 \times 10^{-6}$ $\mu \mathrm{Ci} / \mathrm{cm}^{3}$ of ${ }^{85} \mathrm{Kr}$. The maximum permissible concentration of these radioactive gases can be calculated, 11 and it varies from 2 to $3 \times 10^{-6} \mu \mathrm{Ci} / \mathrm{cm}^{3}$. Before the beam-channel air is to be vented, a reading of $<5 \times 10^{-13}$ A must be sbtained on the kanne instrument. This number is two to three times normal background and relative to ${ }^{85} \mathrm{Kr}$ is like $2 \times 10^{-6} \mathrm{\mu Ci} / \mathrm{cm}^{3}$.

For operational checks, ${ }^{60} \mathrm{Co}$ or ${ }^{137} \mathrm{Cs}$ sources are available and they have been used for this purpose by cross-reference to a well-calibrated victoreen 440 if survey instrument (Fig. 4). For some unkrown reason, the slopes in Figs. 3 and 4 are not the same.

\section{v. DISCIISSION}

This monitoring procedure has been in use for several months and has proved very practical for measuring radioactive air in the accelerator beakn channel. Its real valve is in determining when to vent so as not to exceed acceptable limits for discharge of radioactive gases.

Accelerator radiation background co te a problem where very sensitive monitoring equipment is used to measure radioactive gos concontrations. The normal background is shown on the right in fig. 5 . 

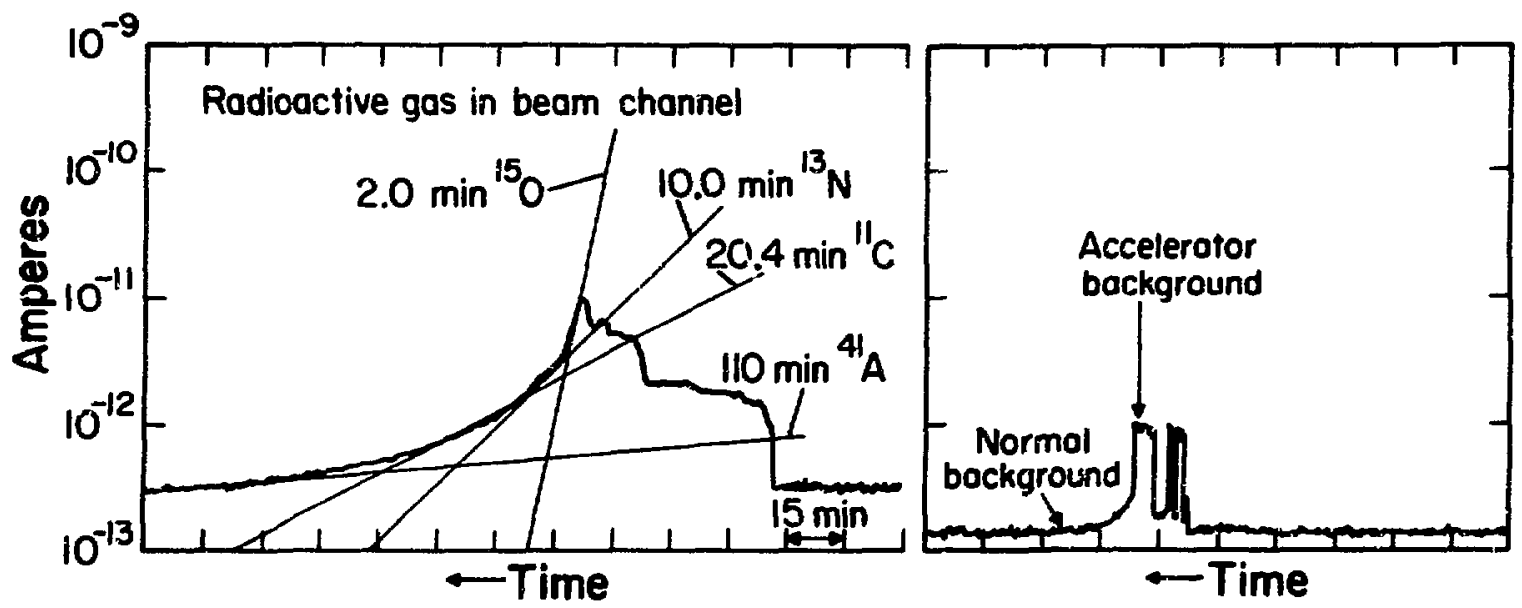

Fig. 5. Kanne chamber response to radinactive gases in the accelerator beam channel.

Also shown is the instrument response to gamma radiation resulting from beam spill along the accelerator structure. This is distinguished by the rapid fall off contrasted to the slower, more gradual decay of radioactive gases (left side of Fig. 5). The half-lives of the isotopes of interest were drawn through the straight sections of the decay curvi. Agreement with radioactive gases expected and those measured is good. When there is no beam spill, normal background measurements persist.

\section{ACKNOHLEDGMENTS}

The Kanne-chamber air sampier was con-

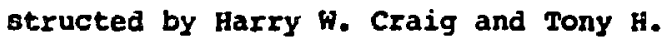

Salazar. We very much appreciate the assistance of Bernard C. Eutsler and Robert $N$. Mitchell in calibrating this instrument.

\section{REFERENCES}

1. A. C. George, A. J. Breslin, J. W. Haskins, Jr., and R. M. Ryan, "Svaluation of the hazard from Radtoactive Gas and Ozone at LInear Electron Accelerators," Proc. U.S. AEC lst Symp. Accelerator Radiation Dosimetry and Experience, 1365, CONF-651109, D. 513 .

2. A. Rindi and St. Charalambus, "Alrborne Radioactivity Produced at High Energy Accelerator:" Nucl. Instr. Methods 47. 227 (1967).
3. H. Vialettes, "Gas and Dust Activation in the Target Room of the Saclay Electron Ifnac," 2nd Intern. Conf. Accelerator nosimetry and Experience, 1969, SLAC, CONE-691101.

4. M. J. Engelke and J. F. Parker, "Generation of Radioaztive $A i r$ and Noxious Gases," LASL internal memo (1967).

5. K. R. Kase, "Radioactive Gas Production at a 100 kev Electron Linac Eacility," University of Cal1fornia Radiation Laboratory report UCRI-1.4662 (1966).

6. J. E. Hoy, "Operational Experience with Kanne Ionization Chambers," Health Phys. E. 203-210 (1961).

7. J. J. Fitzgerald and W. E. Borelli, "Determination of the Efficiency of Kanne Chambers for Detection of Radiogases," Knolls Atomic Propulston Laboratory report RAPL-1231 (1954).

8. G. W. Kartin, J. B. Smathers, and R. D. Neff, "A theoretical Analysis of Proportional Counter Response vs LET," Health Phys. 22, No. 1, 73-77 (1972).

9. U.S. Department of Health, Education and Welfare, Public Health Service, Radiological Health Handbook, PB 121784R, 1960, p. 155 .

10. J. F. Parker and $M$. J. Engelke, "HighIntensity Electron Accelerator Radiation Hazards." in Health Physics Operational Monitoring, Vol. I. C. A. WiIISs and $J_{\text {. S. Hantloser, Eds. (Gordon and }}$ Breach, New York, 1972), p. 179.

11. Report of Comnittee II on Permissible Dose for Internal Radiation, 1959, Health Phys. 3, 6-28 (1960). 


\section{APPENDIX}

OPERATION OF THE MAST OZONE METER

The mobile Kanne chamber and Mast $O_{3}$ detector unit is shown in Fig. 2 .

\section{PRINCIPLES OF OPERATION*}

The concentration of $O_{3}$ in air is measured by the Mast $\mathrm{O}_{3}$ meter or Mast microcoulomb detector. The air sample comes into intimate contact with a thin film of sensing solution on an electrode. The $\mathrm{O}_{3}$ concentration is determined by the oxidationreduction of $\mathrm{KI}$ in the sensing solution. An electrical current directly proportional to the mass per unit time of $\mathrm{O}_{3}$ entering the sensor is produced. The meter output may (1) be read directly from a dial in parts per million per volum z, or (2) be recorded as a voltage and converted to parts per million per volume by calibration.

The Mast meter's normal operating range is 0 to $1 \mathrm{ppm} / \mathrm{vol}$. However, with proper selection of range resistors, it is possible to record $o_{3}$ concentrations in the $0-$ to 0.1-ppm/vol range. (The Threshold Limit Value for occupational exposure to $O_{2}$ is $0.1 \mathrm{ppm} / \mathrm{vol}$.) The natural background of $\mathrm{O}_{3}$ is roughly 0.01 to $0.02 \mathrm{ppm} / \mathrm{vol}$, and it is possible to detect $\mathrm{O}_{3}$ concentrations 20.01 ppm/vol above this background.

-Instruction Manial for Mast Model 724-2 0zone Meter, Mast Development Company, Davenport. Iowa (1969). 